\title{
PENERAPAN SANKSI TERHADAP TINDAK PIDANA PENCUCIAN UANG
}

\author{
Idi Amin \\ Fakultas Hukum, Universitas Mataram \\ Jl. Majapahit 62, Mataram \\ Indonesia \\ Email : idiamin@unram.ac.id
}

\begin{abstract}
Abstrak
Tujuan penelitian ini adalah untuk mengetahui dan menganalisis penerapan hukum sanksi pidana pelaku pasif terhadap tindak pidana pencucian uang. Penelitian ini menggunakan penelitian hukum normatif. Hasil penelitian menunjukkan bahwa sanksi pidana terhadap pelaku pasif tindak pidana pencucian uang berdasarkan pada Pasal 5 Undang-Undang Nomor 8 Tahun 2010, seorang pelaku pasif tindak pidana pencucian uang dapat dikenakan hukuman penjara dan denda.
\end{abstract}

Kata Kunci : Pencucian Uang; Penerapan Sanksi.

\section{A. PENDAHULUAN}

Hukum diartikan sebagai suatu aturan yang derivasi (diturunkan) dari norma-norma yang berkembang di masyarakat, pada dasarnya merupakan seperangkat kesepakatankesepakatan yang telah dinegosiasikan antara anggota komunitas, ${ }^{1}$ digunakan pelindung bagi para individu agar tidak diperlakukan semena-mena di satu pihak, dan di pihak lain hukum merupakan pelindung bagi masyarakat dan negara agar tidak seorangpun melanggar ketentuan-ketentuan yang telah disepakati bersama.

Era globalisasi sekarang ini, yang ditunjukan dengan semakin berkembangnya berbagai bidang, membuat kejahatan atau tindak pidana yang dilakukan oleh seseorang juga semakin dinamis. Seperti beberapa tahun terakhir ini, sering kita mendengar dalam pemberitaan media televisi maupun media elektronik mengenai tindak pidana pencucian uang yang dilakukan oleh pejabatpejabat negara.

Melihat keadaan yang akhir-akhir ini sering kita lihat dan dengar ,mungkin sudah tidak asing lagi dengan kasus Pencucian Uang yang beberapa tahun terakhir ini menjadi

${ }^{1}$ Hasanuddin AF, et.al. (2003). Pengantar Ilmu Hukum. Jakarta: Kerja sama antara Pustaka al-Husna dengan UIN Press, hlm. 1 bahan pembicaraan di berbagai media di negara kita. Mengenai pengertian pencucian uang, yang dimaksud dengan pencucian uang (money laundering) itu sendiri adalah suatu upaya perbuatan dengan maksud menutupnutupi uang/dana dari hasil perbuatan kejahatan melalui transaksi keuangan dengan maksud uang atau harta kekayaan tersebut tampak seolah-olah berasal dari kegiatan yang sah/legal.

Indonesia merupakan salah satu negara yang cukup terbuka menjadi sasaran pemutihan uang, karena di Indonesia terdapat faktor-faktor potensial sebagai daya tarik bagi pelaku money laundering, gabungan antara kelemahan sistem sosial dan celahcelah hukum dalam sistem keuangan antara lain sistem devisa bebas, tidak diusutnya asalusul yang ditanamkan dan perkembanganya pasar modal, pedagang valuta asing dan jaringan perbankan yang telah meluas ke luar negeri. Melihat besarnya dampak yang ditimbulkannya terhadap stabilitas pekonomian negara, maka sejumlah negara telah menetapkan aturan yang cukup ketat guna mengungkap money laundering.

Dalam tindak pidana pencucian uang terkait dua tindak pidana, yaitu kejahatan menghasilkan uang haram dan pencucian uang haram. Kualifikasi dalalm perbuatan tersebut dirumuskan sebagai penempatan 
harta kekayaan yang diketahuinya atau patut diduganya merupakan hasil tindak pidana ke dalam penyedia jasa keuangan maupun yang lainnya, baik atas nama sendiri atau atas nama orang lain. Berdasarkan ketentuan ini maka adanya perbuatan korupsi tidak perlu dibuktikan terlebih dahulu, cukup kalau ada pengetahuan atau dugaan bahwa uang haram tersebut berasal dari perbuatan korupsi.

Bicara penerapan hukum tidak bisa lepas dari alat penegak hukum yang menjalankan fungsi pengawasan dan penegakan hukum. Dalam menjalankan tugasnya, penegak hukum tidak semata-mata bertolak pada kekuasaan dan kewenangan yang ada padanya sesuai dengan ketentuan hukum yang berlaku, tetapi juga wajib melayani kebutuhan hukum individu dan kebutuhan masyarakat atau negara sebagai salah satu kesatuan secara serasi dan seimbang. Aparat hukum harus berani mengambil langkahlangkah secara tegas kepada setiap pelanggar hukum dan melindungi setiap orang dari tindakan pelanggaran hukum.

Berdasarkan uraian di atas, maka ruang lingkup masalah dalam penelitian ini adalah bagaimana penerapan hukum sanksi pidana pelaku pasif terhadap tindak pidana pencucian uang ?

\section{B. METODE PENELITIAN}

Penelitian ini adalah penelitian Normatif. Penelitian hukum normatif di sebut juga penelitian hukum doktrinal. Pada penelitian hukum jenis ini, acapkali hukum di konsepkan sebagai apa yan tertulis dalam peraturan perundang-undangan (Law in books) atau hukum di konsepkan sebagai kaidah atau norma yang merupakan patokan berprilaku manusia yang di anggap pantas.

Sehubungan dengan hal penelitian normatif, maka akan digunakan pendekatan yaitu pendekatan perundang-undangan (statute approach). Sumber dan jenis bahan hukum bersumber dari peraturan perundangundangan dan berbagai literature yang terkait dengan pokok permasalahan. Teknik pengumpulan bahan hukum yang peneliti gunakan dalam penelitian normatif ini adalah dengan menggunakan studi dokumen. Analisis dengan menggunakan penalaran hukum dan/atau dilakukan interpretasi untuk dapat memecahkan isu hukum berdasarkan doktrin, teori dan asas atau prinsip hukum yang dikemukakan oleh ahli atau sarjana hukum.

\section{PEMBAHASAN}

Kejahatan merupakan sebuah istilah yang sudah lazim dan populer dikalangan masyarakat Indonesia atau crime bagi orang Inggris. Menurut Hoefnagels, kejahatan merupakan suatu pengertian yang relatif. Banyak pengertian yang digunakan dalam ilmu-ilmu sosial yang berasal dari bahasa sehari-hari tidak memberikan gambaran yang jelas tentang kejahatan, tetapi hanya merupakan suatu ekspresi dalam melihat perbuatan tertentu. ${ }^{2}$

Tindak Pidana Pencucian Uang merupakan salah satu tindak pidana yang berasal dari hasil ratifikasi dari hasil Perjanjian Internasional yang dibuat oleh negara negara yang tergabung dalam anggota Financial Action Task Force on Money Laundering ( FATF ), tindak pidana pencucian uang bukan berarti mencuci uang. Tindak Pidana Pencucian Uang adalah upaya pelaku kejahatan untuk menyamarkan harta kekayaan yang dimana harata kekayaan tersebut yang merupakan hasil kejahatan sehingga harat kekayaan yang didapat secara ilegal terlihat seolah olah sebagai harta kekayaan yang legal.

Secara terpisah Sutan Remy Sjahdeini mendefiniskan pengertian dari money laundering yaitu suatu perbuatan yang dilakukan oleh seseorang ataupun organisasi terhadap hasil kekayaan yang diperoleh dari Tindak Pidana, dengan tujuan menyembunyikan, menyamarkan asal usul uang tersebut dari pemerintah ataupun otoritas yang berwenang melakukan penindakan

${ }^{2}$ Aziz Syamsuddin. (2011). Tindak Pidana Khusus. Cet. Ke-2. Jakarta: Sinar Grafika, hlm. 17 
terhadap tindak pidana dengan cara antara lain dan terutama memasukkan uang tersebut dalam sistem keuangan (financial system). Sehingga uang tersebut kemudian dapat dikeluarkan denga sistem keuangan tersebut sebagai uang yang halal. ${ }^{3}$

Secara umum pengertian pencucian uang adalah suatu proses atau perbuatan yang betujuan untuk menutupi/menyamarkan asal dari uang atau harta yang diperoleh dari hasil kejahatan yang kemudian dijadikan harta kekayaan yang seolah-olah berasal dari kegiatan yang sah. ${ }^{4}$

Istilah pencucian uang atau money laundering telah dikenal sejak tahun 1930 di Amerika Serikat, yaitu ketika seorang penjahat terbesar di Amerika yang bernama Al Capone, mencuci uang hitam dari usaha kejahatannya dengan memakai Meyer Lansky, orang Polansia, yaitu seorang akuntan, mencuci uang kejahatan Al Capone melalui usaha binatu (laundry). ${ }^{5}$

Pengkriminalisasian Tindak Pidana pencucian Uang oleh Indonesia sejak organisasi Internasional yang memberantas Tindak Pidana Pencucian uang yaitu Financial Action Task Force on Money Laundering (FATF )yang kemudian memasukkan indonesia dalam daftar Non Cooperative Countries and Territories, karena Indonesia : 6

1. Tidakadanyaketentuan yang menempatkan Money Loundering sebagai Tindak Pidana

2. Tidak adanya ketentuan prinsip mengenai nasabah (know your costumer - KYC) untuk lembaga keuangan non Bank

3. Rendahnya kapasitas dalam penanganan kejahatan pencucian uang dan

\footnotetext{
${ }^{3}$ Sutan Remy Sjahdeini. (2007). Seluk-Beluk Tindak Pidana Pencucian Uang dan Pembiayaan Terorisme, Jakarta: Pustaka Utama Grafiti, hlm. 5.

${ }^{4}$ Adrian Sutedi. (2013). Pasar Modal Mengenal Nasabah Sebagai Pencegahan Pencucian Uang. Bandung: Alfabeta, hlm. 9 .

${ }^{5}$ Adrian Sutedi. (2010). Hukum Perbankan Suatu Tinjauan Pencucian Uang Merger, Likuidasi dan Kepailitan. Jakarta: Sinar Grafika, hlm 17

${ }^{6}$ Yunus Husein. (2008). Negeri sang Pencuci Uang, Jakarta: Pustaka Juanda Tiga Lima, hlm. 91
}

4. Kurangnya kerja sama Internasional dalam Penanganan kejahatan Tindak Pidana Pencucian Uang.

Pada mulanya praktik tindak pidana pencucian uang di Indonesia di atur dalam Undang-Undang No 15 tahun 2002 namun karena Undang-Undang Ini di anggap sudah tidak sesuai lagi dengan perkembangan zaman dan tidak mampu lagi memenuhi kebutuhan dalam pemberantasan Tindak Pidana Pencucian Uang maka dibentuklah Undang-Undang No 8 Tahun 2010 yang masih kita gunakan hingga sekarang ini sebagai dasar pemidanaan dalam pelanggar Kejahatan Tindak Pidana Pencucian Uang.

Unsur-Unsur tindak pidana pencucian uang berdasarkan ketentuan pasal-pasal 3,4,5,6,7,8,9, dan 10 Undang-Undang Nomor 8 Tahun 2010, yang termasuk ke dalam unsurunsur tindak pidana pencucian uang adalah: ${ }^{7}$

1. Setiap orang baik orang perseorangan maupun korporatif dan personil pengendali korporasi.

2. Menempatkan, mentransfer, mengalihkan, membelanjakan, membayarkan, menghibahkan, menitipkan, membawa ke luar negeri, merubah bentuk, menukarkan dengan mata uang atau surat berharga atau perbuatan lain atas Harta kekayaan yang diketahuinya/patut diduganya merupakan hasil kejahatan pidana sebagaimana ditentukan pada Pasal 2 ayat (1) UndangUndang Nomor 8 Tahun 2010.

3. Menerimaataumenguasai,mentransferkan, melakukanpembayaran, hibah,sumbangan, penitipan, penukaran atau menggunakan harta kekayaan yang diketahuinya atau patut diduganya merupakan hasil kejahatan sebagaimana ditentukan pada Pasal 2 Ayat (1) Undang-Undang Nomor 8 Tahun 2010.

4. Bertujuan untuk menyembunyikan atas harta kekayaan yang diketahuinya atau patut diduganya merupakan hasil kejahatan sebagaimana ditentukan pada Pasal 2 Ayat (1) Undang-Undang Nomor 8 Tahun 2010.

\footnotetext{
${ }^{7}$ Aziz Syamsuddin. (2011). Tindak Pidana Khusus. Cet.
} Ke-II. Jakarta: Sinar Grafika, hlm. 24 
Bahwa terjadinya suatu kejahatan pencucian uang terlebih dahulu ada tindak pidana/kejahatan lain yang telah dilakukan oleh pelaku Tindak Pidana Pencucian Uang sebagaimana yang telah ditentukan secara limitatif dalam Pasal 2. Selanjutnya Pasal 3 menyatakan:

"Setiap orang yang menempatkan, mentransfer, mengalihkan, membelanjakan, membayarkan, menghibahkan, menitipkan, membawa keluar negeri. Mengubah bentuk, menukarkan dengan mata uang atau surat berharga atau perbuatan lain atas harta kekayaan yang diketahuinya atau patut diduganya merupakan hasil tindak pidana sebagaimana dimaksud dalam Pasal 2 ayat (1) dengan tujuan menyembunyikan atau menyamarkan asal usul harta kekayaan dipidana karena tindak pidana pencucian uang dengan pidana penjara paling lama 20 (dua puluh) tahun dan denda paling banyak Rp. 10.000.000.000,00 (sepuluh miliar rupiah)."

Pasal 4 menyatakan :

"Setiap orang yang menyembunyikan atau menyamarkan asal usul, sumber, lokasi, peruntukan, pemgalihan hak-hak atau kepemilikan yang sebenarnya atas harta kekayaan yang diketahuinya atau patut diduganya merupakan hasil tindak pidana sebagaimana dimaksud dalam Pasal 2 ayat (1) dipidana karena tindak pidana pencucian uang dengan pidana penjara paling lama 20 (dua puluh) tahun dan denda paling banyak Rp. 5.000.000.000,00 (lima miliar rupiah)."

Pasal 5 menyatakan:

1. Setiap orang yang menerima atau menguasai penempatan, pentransferan, pembayaran, hibah, sumbangan, penitipan, penukaran, atau menggunakan harta kekayaan yang diketahuinya atau patut diduganya merupakan hasil tindak pidana sebagaimana dimaksud dalam Pasal 2 ayat (1) dipidana dengan pidana penjara paling lama 5 (lima) tahun dan denda paling banyak Rp. 1.000.000.000,00 (satu miliar rupiah)

2. Ketentuan sebagaimana dimaksud pada ayat (1) tidak berlaku bagi pihak pelapor yang melaksanakan kewajiban pelaporan sebagaimana diatur dalam Undang-Undang ini.

Ketentuan pada Pasal 3, 4, dan 5 tersebut sejalan dengan ketentuan Pasal 2 yang menjelaskan adanya perbuatan awal dalam melakukan kejahatan pencucian uang. Dengan kata lain, untuk menetapkan telah terjadi suatu kejahatan tindak pidana pencucian uang dan pelakunya, maka terlebih dahulu dibuktikan adanya kejahatan awal. Akan tetapi ketentuan itu menjadi tidak jelas atau kontradiktif dengan adanya ketentuan pada Pasal 69 yang menyebutkan :

Untuk dapat dilakukan penyidikan, penuntutan, dan pemeriksaan di sidang pengadilan terhadap tindak pidana pencucian uang tidak wajib dibuktikan terlebih dahulu tindak pidana asalnya.

Ketentuan pada pasal di atas mengakibatkan tidak adanya kepastian hukum dan dapat disalahgunakan oleh aparat penegak hukum karena jelas-jelas Pasal 2, 3, 4, dan 5 mengatakan dengan tegas bahwa untuk Tindak Pidana Pencucian Uang harus ada tindak pidana asal dan ini harus dibuktikan terlebih dahulu atau setidaktidaknya dibuktikan secara kebersamaan.

Penulis memiliki pandangan yang sama dengan apa yang di maksud dalam Pasal 5 ayat 1 ini, bahwa seseorang yang menerima atau memanfaatkan uang yang patut diduganya merupakan hasil dari tindak pidana pencucian uang, maka orang tersebut bisa diberikan sanksi sesuai dengan isi pasal 5 ayat UndangUndang Nomor 8 Tahun 2010 tersebut.

Yang dimaksud dengan "patut diduganya" adalah suatu kondisi yang memenuhi setidaktidaknya pengetahuan, keinginan, atau 
tujuan pada saat terjadinya transaksi yang diketahuinya yang mengisyaratkan adanya pelanggaran hukum. Ketika ada pencucian aktif pasti ada pencucian pasifnya, yang jelas di dalam hukum penerima pasif itu adalah bagian dari pencucian uang.

Adapun sanksi hukum yang dapat dikenakan kepada pelaku tindak pidana pencucian uang berupa ancaman pidana penjara dan denda yang diatur pada ketentuan Pasal 3, Pasal 4, Pasal 5 ayat (1), Pasal 6 ayat (1), dan (2), Pasal 7 ayat (1) dan (2), Pasal 8, Pasal 9 ayat (1) dan (2), Pasal 10 UndangUndang Nomor 8 Tahun 2010.

Pada Pasal 6 ayat (1) Undang-Undang Nomor 8 Tahun 2010 berbunyi: "Dalam hal tindak pidana pencucian uang sebagaimana diaksud dalam pasal 3, pasal 4, dan pasal 5 dilakukan oleh korporasi pidana dijatuhkan terhadap korporasi dan/atau Personil pengendali Korporasi."

Pasal 6 ayat (2) Undang-Undang Nomor 8 Tahun 2010 berbunyi: "Pidana dijatuhkan terhadap korporasi apabila tindak pidana pencucian uang .

1. Dilakukan atau diperintahkan oleh personil pengendali korporasi.

2. Dilakukan dalam rangka pemenuhan maksud dan tujuan korporasi.

3. Dilakukan sesuai dengan tugas dan fungsi pelaku atau pemberi perintah, dan.

4. Dilakukan dengan maksud memberikan manfaat bagi korporasi."

Dalam Pasal 6 ayat (1) dan (2) ini berisi tentang tindak pidana pencucian uang yang dilakukan oleh korporasi. Korporasi itu sendiri adalah kelompok yang terorganisasi yaitu kelompok terstruktur yang terdiri dari 3 (tiga) orang atau lebih, yang eksistensinya untuk waktu tertentu, dan bertindak dengan tujuan melakukan satu atau lebih tindak pidana yang diatur dalam Undang-Undang ini dengan tujuan memperoleh keuntungan finansial atau non-finansial baik secara langsung maupun tidak langsung.

Pasal 7 ayat (1) Undang-Undang Nomor 8 Tahun 2010 menyatakan: "Pidana pokok yang dijatuhkan terhadap koorporasi adalah pidana denda paling banyak Rp 100.000.000.000.00, (seratus miliar rupiah)."

Pasal 7 ayat (2) Undang-Undang Nomor 8 Tahun 2010 berbunyi: "Selain pidana denda sebagaimana dimaksud pada ayat (1), terhadap korporasi juga dapat dijatuhkan pidana tambahan berupa:

1. Pengumuman putusan hakim;

2. Pembekuan sebagian atau seluruh kegiatan usaha korporasi;

3. Pencabutan izin usaha;

4. Pembubarandan/ataupelarangankorporasi;

5. Perampasan aset korporasi untuk negara; dan/atau

6. Pengambilalihan korporasi oleh negara."

Pasal 7 ayat (1) dan (2) ini berisi tentang sanksi pidana yang diterima oleh korporasi apabila terbukti telah melakukan tindak pidana pencucian uang. Penulis melihat sanksi yang dijelaskan dalam Pasal 7 ayat (1) dan (2) ini sangat jelas dan tegas.

Penjelasan dari masing-masing Pasal yang penulis tuliskan diatas sudah sangat jelas, dimana bahwa seorang pelaku tindak pidana pencucian uang tersebut akan menerima sanksi pidana, baik itu statusnya sebagai pelaku aktif, pelaku pasif ataupun atas nama korporasi. Sanksi yang diberikan cukup setimpal dengan apa yang telah dilakukan oleh si pelaku tindak pidana tersebut, baik sanksi denda yang harus dibayarkan ataupun pidana kurungan yang dijalaninya.

Dari uraian diatas sangat lah jelas bentuk dari berbagai macam hukuman yang diterima oleh pelaku pencucian uang. Untuk lebih jelasnya ancaman pidana terhadap pelaku kejahatan pencucian uang pasif yang terdapat pada Undang-Undang Nomor 8 Tahun 2010 tentang Pencegahan Dan Pemberantasan Tindak Pidana Pencucian Uang sebagai berikut.

Pasal 5 menyatakan bahwa;

"Setiap orang yang menerima atau menguasai penempatan, pentransferan, pembayaran, hibah, sumbangan, penitipan, penukaran, atau menggunakan harta kekayaan yang diketahuinya atau patut diduganya merupakan hasil tindak pidana 
sebagaimana dimaksud dalam Pasal 2 ayat (1) dipidana dengan pidana penjara paling lama 5 (lima) tahun dan denda paling banyak Rp. 1.000.000.000,00 (satu miliar rupiah)"

Yang dimaksud dengan "patut diduganya" adalah suatu kondisi yang memenuhi setidaktidaknya pengetahuan, keinginan, atau tujuan pada saat terjadinya. Transaksi yang diketahuinya yang mengisyaratkan adanya pelanggaran hukum.

Unsur-unsur perbuatan yang terdapat pada pasal 5 ayat (1), adalah sebagai berikut: ${ }^{8}$

1. Unsur setiap orang;

2. Unsur menerima atau menguasai penempatan, pentransferan, pembayaran, hibah, sumbangan, penitipan, penukaran, atau menggunakan;

3. Harta kekayaan;

4. Yang diketahuinya atau patut diduganya merupakanhasiltindakpidanasebagaimana dimaksud dalam Pasal 2 ayat (1).

\section{KESIMPULAN}

Pelaku pasif tindak pidana pencucian uang dapat dikenakan sanksi berdasarkan Pasal 5 Undang-Undang Nomor 8 Tahun 2010, berkaitan dengan menerima atau menguasai penempatan, pentransferan, pembayaran, hibah, sumbangan, penitipan, penukaran, atau menggunakan harta kekayaan yang diketahuinya atau patut diduganya merupakan hasil tindak pidana. Sanksi pidana penjara paling lama 5 (lima) tahun dan denda paling banyak Rp. 1.000.000.000,00 (satu miliar rupiah). "Patut Diduganya" adalah suatu kondisi yang memenuhi setidak-tidaknya pengetahuan, keinginan, atau tujuan pada saat terjadinya.

\section{DAFTAR PUSTAKA}

\section{Buku}

Hasanuddin AF, et.al. (2003). Pengantar Ilmu
Hukum, Jakarta: Kerja sama antara Pustaka al-Husna dengan UIN Press.

Kristiana, Yudi. (2015)). Pemberantasan Tindak Pidana Pencucian Uang : Perspektif Hukum Progresif, Yogyakarta: Thafa Media. Yogyakarta.

Sjahdeini, Sutan Remy. (2007). Seluk-Beluk Tindak Pidana Pencucian Uang dan Pembiayaan Terorisme. Jakarta: Pustaka Utama Grafiti.

Sutedi, Adrian. (2010). Hukum Perbankan Suatu Tinjauan Pencucian Uang Merger, Likuidasi dan Kepailitan. Jakarta: Sinar Grafika.

Sutedi, Adrian. (2013). Pasar Modal Mengenal Nasabah Sebagai Pencegahan Pencucian Uang. Bandung: Alfabeta.

Syamsuddin, Aziz. (2011). Tindak Pidana Khusus. Cet. Ke-II. Jakarta: Sinar Grafika.

Yunus Husein. (2008). Negeri sang Pencuci Uang. Jakarta: Pustaka Juanda Tiga Lima.

\section{Undang-Undang}

Indonesia, Undang-Undang Nomor 8 Tahun 2010 tentang Pencegahan dan Pemberantasan Tindak Pidana Pencucian Uang.

${ }^{8}$ Yudi Kristiana, Pemberantasan Tindak Pidana Pencucian Uang :Perspektif Hukum Progresif, 2015, Thafa Media , Yogyakarta, hlm 69-71. 